\title{
Improving students' mathematics learning outcomes through the implementation of think-pair-share model
}

\author{
Sitti Rahmah Tahir ${ }^{1}$, Muhammad Irfan Basri ${ }^{2}$, Andi Mulawakkan Firdaus ${ }^{3 *}$ \\ ${ }^{1,2,3}$ Universitas Muhammadiyah Makassar, Jalan Sultan Alauddin No.259 Kota Makassar, Indonesia
}

\begin{tabular}{|c|c|}
\hline A R T I C L E I N F O & A B S T R A C T \\
\hline $\begin{array}{l}\text { Original Article } \\
\text { doi: } 10.18860 / \text { ijtlm.v2i2.7609 }\end{array}$ & $\begin{array}{l}\text { This research is a classroom action research which aims to improve } \\
\text { mathematics learning outcomes through the application of the }\end{array}$ \\
\hline Keywords: & Think-Pair-Share type of cooperative learning model. The research \\
\hline $\begin{array}{l}\text { Think-Pair-Share, } \\
\text { Mathematics Learning }\end{array}$ & $\begin{array}{l}\text { subjects were } 25 \text { tenth grade students who consisted of } 9 \text { male } \\
\text { students and } 16 \text { female students. The instruments used were }\end{array}$ \\
\hline Outcomes, Student Activities & $\begin{array}{l}\text { observation sheets, response questionnaires, and learning outcomes } \\
\text { tests. Data collection techniques in this study were information on } \\
\text { student activities, implementation of actions, and students' learning } \\
\text { outcomes. Data on the observations of student activities and } \\
\text { response questionnaires will be analyzed qualitatively, whereas data } \\
\text { on students' learning outcomes will be analyzed quantitatively } \\
\text { using descriptive statistics. The results of this study showed that the } \\
\text { application of the cooperative learning model with Think-Pair- } \\
\text { Share model can improve students mathematics learning } \\
\text { outcomes. }\end{array}$ \\
\hline
\end{tabular}

(C) 2019 IJTLM. All rights reserved.

*Corresponding author.

E-mail: andi.mulawakkan@unismuh.ac.id

How to cite: Tahir, S. R., Basri, M. I., \& Firdaus, A. M. (2019). Improving students' mathematics learning outcomes through the implementation of think-pair-share model. International Journal on Teaching and Learning Mathematics, 2(2), 67-77.

\section{INTRODUCTION}

Mathematics is a subject that is always taught in every level of education. This shows that mathematics plays an important role in efforts to improve the quality of human resources (van Es et al., 2017). Besides, mathematics is also a means to think logically, systematically and critically. Because mathematics is abstract, it needs a way to manage the teaching and learning process so that mathematics is easily digested by students and is more meaningful and beneficial for their lives (Almerino et al., 2019; Kuznetsova \& Matytcina, 2018). Therefore, a teacher must be smart in choosing a learning model. The application of learning models that are in accordance with the material taught is expected to improve the learning process so that in the end the results of students' mathematics learning can be improved.

Based on the results of preliminary observations at SMAN 8 Pangkep especially in class X3, information was obtained from the mathematics study teachers that the average value of students from the Mid semester exam results was 54.78. This shows that the mathematics learning outcomes of students at these schools have not yet been satisfactory. The low student learning outcomes for mathematics subjects are caused by several things, including students' motivation to learn mathematics are still lacking (Githua \& Mwangi, 2003; Kiemer et al., 2015; $\mathrm{Ng}, 2018$ ), attitudes toward mathematics are sometimes negative (Di Martino \& Zan, 2010; Zan \& Di Martino, 2007) and most importantly are teachers who apply teaching methods that 
sometimes do not fit the characteristics of mathematics itself (Gravemeijer et al., 2017). Students are mostly just listeners and recipients of information from teachers, whereas the methods used by teachers in the process of learning mathematics are one of the determining factors in increasing students' success in learning.

One effort that can be done to improve the learning outcomes of mathematics at Pangkep 8 High School is to try to apply a cooperative learning model. Cooperative learning is one group learning model that has certain rules. The basic principle of cooperative learning is that students form small groups and teach each other to achieve common goals (Huang et al., 2017; Munir et al., 2018). In cooperative learning, one type commonly used is the type of Think-Pair-Share (TPS). Frank Lyman in 1985 and his colleague stated that, Think-Pair-Share is an effective way to vary the atmosphere of class discussion patterns. The advantage of the class discussion model is discussions involve all students directly, each student can test the level of knowledge and mastery of each subject matter, by submitting and maintaining his opinion in the discussion that students are expected to gain self-confidence themselves, and discussions can support efforts to develop social attitudes and democratic attitudes of students (Chen et al., 2018; Cotton et al., 2007; Johnson et al., 2007).

The core activities of TPS learning have three stages, namely (1) the stage of thinking (think), (2) the stage of pairing (pair) and (3) the stage of sharing (share). TPS is a type of learning model that is easy to implement so that students can cooperate, help each other, learn information or skills and have a scoring system of increasing individuals and working together in groups. Then in the cooperative learning model TPS type is an effective way to change learning in the classroom. By applying the Think Pair Share (TPS) type of cooperative learning model, it is expected that it can increase student participation and provide more opportunities to contribute to each group member (Mundriyah \& Parmawati, 2016).

The result of research from Siregar et al. (2017) indicated that there was improvement of students' mathematical problem-solving abilities after applying the cooperative learning model TPS type. Firdaus (2019) showed that the Cooperative TPS model give a positive impact on students' communication ability. Fauzi and Fikri (2018) reported that using the TPS learning model can increase student learning activities. Hence, it is necessary to do research on the application of the TPS type of cooperative learning model.

\section{METHOD}

The type of this study is Classroom Action Research which is carried out on a cyclical basis. Each cycle in Kemmis and Taggart model consists of 4 stages, namely planning, action, observation and evaluation, and reflection (Kemmis et al., 2013). This research was conducted at SMAN 8 Pangkep with research subjects of class $\mathrm{X}$ students as many as 25 people consisting of 9 male students and 16 female students.

In this study, the instruments used were observation sheets, response questionnaires, and learning outcomes tests. The data collection techniques in this study are data on student activities, implementation of actions, and mathematics learning outcomes of students in participating in TPS cooperative learning. Data that has been collected will then be analyzed. Data on the observations of student activities and response questionnaires will be analyzed qualitatively. While data on learning outcomes will be analyzed quantitatively using descriptive statistics with the help of SPSS for Windows (SPSS 18.0 for Windows).

The criteria used to determine the category of mathematics learning outcomes are based on the categorization technique set by the Ministry of National Education (Firdaus, 2019), namely: 
Table 1. Standard categorization based on provisions ministry of education

\begin{tabular}{cc}
\hline Score & Category \\
\hline $00-54$ & Very low \\
$55-64$ & Low \\
$65-79$ & Is being \\
$80-89$ & High \\
$90-100$ & Very high \\
\hline
\end{tabular}

\section{RESULTS AND DISCUSSION}

\subsection{Description of Research Results in Cycle I}

In the first cycle consists of 4 meetings, namely 3 times the learning process with the material quadratic function.

\subsubsection{Planning}

(1) Review the material taught. (2) Creating a Learning Implementation Plan (RPP) that reflects.

(3) Making Student Worksheets in each learning process. (4) Make an observation sheet to observe student activities. (5) Make a questionnaire to find out student responses. (6) Make a test of learning outcomes for cycle I.

\subsubsection{Action}

(1) At the beginning of the face-to-face meeting, the teacher explains the material according to the plan for implementing the learning. (2) The teacher divides students into several Think-PairShare (TPS) groups consisting of two students. (3) The teacher poses problems on student worksheets and provides opportunities for students to think individually. (Phase 1 TPS: Think). (4) The teacher directs students to discuss with their partners. (Phase 2 TPS: Pair). (5) The teacher asks several groups (pairs) to present the results of the discussion and ask students from other groups to respond (Phase 3 TPS: Share). (6) The teacher provides opportunities for students to ask questions that have not been understood. (7) The teacher gives an award to the group that presents the results of the discussion. (8) At the end of the meeting, the teacher gives homework to be done individually.

\subsubsection{Observating}

At this stage the observation is carried out to observe the activities of students during the learning process taking place using the cooperative learning type Think-Pair-Share (TPS). The results of observations of student activities can be seen in Table 2 .

Table 2. Results of observation of student activities during Cycle I

\begin{tabular}{|c|c|c|c|c|c|c|c|}
\hline \multirow{2}{*}{ No. } & \multirow{2}{*}{ Aspects studied } & \multicolumn{4}{|c|}{ Meeting } & \multirow{2}{*}{ Percentage } & \multirow{2}{*}{$\begin{array}{l}\text { Amount } \\
(\%)\end{array}$} \\
\hline & & $\mathrm{I}$ & II & III & IV & & \\
\hline 1. & $\begin{array}{l}\text { Students present during the learning } \\
\text { process take place. }\end{array}$ & 23 & 24 & 20 & \multirow{4}{*}{$\begin{array}{l}\mathrm{T} \\
\mathrm{E} \\
\mathrm{S} \\
\mathrm{T}\end{array}$} & 67 & 89,32 \\
\hline 2. & $\begin{array}{l}\text { Students who ask questions to the } \\
\text { teacher. }\end{array}$ & 4 & 5 & 6 & & 15 & 20 \\
\hline 3 & $\begin{array}{c}\text { Students who answer the problem } \\
\text { questions taught by the teacher. }\end{array}$ & 3 & 5 & 4 & & 12 & 16 \\
\hline 4. & $\begin{array}{l}\text { Active students come to the front of } \\
\text { the class doing independent }\end{array}$ & 4 & 6 & 5 & & 15 & 20 \\
\hline
\end{tabular}




\begin{tabular}{|c|c|c|c|c|c|c|}
\hline \multicolumn{5}{|c|}{ assignments. } & & \\
\hline 5. & $\begin{array}{l}\text { Students who actively work together } \\
\text { during discussion in pairs. }\end{array}$ & 20 & 22 & 18 & 60 & 80 \\
\hline 6. & $\begin{array}{l}\text { Students who can present the results } \\
\text { of group discussions. }\end{array}$ & 8 & 10 & 6 & 24 & 32 \\
\hline 7. & $\begin{array}{l}\text { Students who do other activities } \\
\text { (noisy, playing, etc.). }\end{array}$ & 5 & 6 & 4 & 15 & 20 \\
\hline
\end{tabular}

In the first cycle students activities carried out during the learning process take place. Based on the student activity sheet in Table 2, it can be seen that: Students who attended the learning process took place, at the first meeting as many as 23 students then increased in the second meeting as many as 24 people and decreased to the third meeting as many as 20 people. Students who ask questions to the teacher, at the first meeting as many as 4 people then increase in the second meeting as many as 5 people and again increase in the III meeting as many as 6 people. Students who answer the problem questions taught by the teacher, at the first meeting as many as 3 people then increase in the second meeting as many as 5 people and at the III meeting as many as 4 people. Active students come forward to work on independent assignments, at the first meeting as many as 4 people then increase in the second meeting as many as 6 people and at the III meeting as many as 5 people. Students who actively discuss with their partners (Pair), at the first meeting as many as 20 people then increased in the second meeting as many as 22 people and decreased at meeting III as many as 18 people. Students who present the results of their discussion in front of the class (Share), at the first meeting as many as 8 people then increased in the second meeting as many as 10 people and decreased at the meeting III as many as 6 people. Students who do other activities (playing, noisy, etc.), at the first meeting as many as 5 people and increase in the second meeting as many as 6 people then decrease in meeting III as many as 4 people.

\subsubsection{Evaluation}

The evaluation was carried out at the end of the first cycle to find out the extent of students' understanding of the material being taught. The instrument used was a test of learning outcomes in the form of daily tests after presentation of material for 3 meetings. The score for the acquisition of student learning outcomes after the application of the cooperative learning model type Think-Pair-Share in the first cycle in Table 3.

Table 3. Statistics on the value of student learning outcomes in Cycle I

\begin{tabular}{lc}
\hline Statistics & Statistical Value \\
\hline Subject & 25 \\
Ideal score & 100 \\
Highest score & 82 \\
Lowest score & 44 \\
Score range & 38 \\
Average score & 65 \\
Mode & 65 \\
Median & 65 \\
Variance value & 106.33 \\
Standard deviation & 10.31 \\
\hline
\end{tabular}

After the score of learning outcomes is grouped into five categories, the frequency distribution and percentage are presented in Table 4. 
International Journal on Teaching and Learning Mathematics

2019, Vol. 2, No. 2, pp. 67-77

P-ISSN: 2621-2188, E-ISSN: 2621-2196

Table 4. Frequency distribution and percentage of learning outcomes scores in Cycle I

\begin{tabular}{ccccc}
\hline No. & Score & Category & Frequency & Percentage \\
\hline 1. & $0-54$ & Very low & 4 & 16 \\
2. & $55-64$ & Low & 13 & 52 \\
3. & $65-79$ & Is being & 6 & 24 \\
4. & $80-89$ & High & 2 & 8 \\
5. & $90-100$ & Very high & 0 & 0 \\
\hline \multicolumn{5}{r}{} \\
\hline
\end{tabular}

Based on Tables 3 and 4, it can be stated that students' mathematics learning outcomes after the action taken in the form of the cooperative learning model type Think-Pair-Share (TPS) in the first cycle average score of 65 from the ideal score of 100 are in the medium category. In addition, the highest score was 82 and the lowest score was 44 . Of the 25 students of class X3 of SMA Negeri 8 Pangkep, there were $16 \%$ of students whose learning rates were in the very low category, $52 \%$ were in the low category, $24 \%$ were in the moderate category, and in the high category $8 \%$ while in the very high category $0 \%$.

To see the percentage of completeness of learning mathematics students of class X3 Pangkep 8 High School after applying the cooperative model Think-Pair-Share (TPS) type in the first cycle can be seen in Table 5. Table 5 shows the percentage of students' mathematics learning outcomes in the complete category of $24 \%$, namely 6 out of 25 students, while those included in the incomplete category were $76 \%$, namely 19 out of 25 students.

Table 5. Description of completeness of mathematics learning outcomes in Cycle I

\begin{tabular}{clcc}
\hline Score & Category & Frequency & Percentage \\
\hline $0-74$ & Not completed & 19 & 76 \\
$75-100$ & Completed & 6 & 24 \\
\hline & Total & 25 & 100 \\
\hline
\end{tabular}

\subsubsection{Reflecting}

From the results of the study indicate that the indicators of success in this study have not been achieved in the first cycle, it appears that in cycle I there are still many shortcomings, especially at meeting 1, the actions taken have not shown significant changes. Students do not understand what should be done during group activities. This is because they are not familiar with TinkPair-Share (TPS) type cooperative learning. There are still many students who work independently even though they have been directed to share thoughts in pairs (Pairing). They prefer to ask the teacher rather than discuss with their own friends and consider the teacher's answers correct. In addition, students have not dared to ask questions, and very few present the results of the discussion. Teachers are also constrained by time, because most students are still slow and less serious in carrying out activities according to the instructions in the student worksheets and there are still many students who do other activities, such as noisy, playing, going out of class so that it interferes with the teaching and learning process.

At the end of the first cycle, the teacher gave a test of mathematics learning outcomes and tried to tighten supervision in the hope that the results obtained were pure results and truly measured the students' ability to the material provided. Even so, there are still students who try to imitate their work due to their previous habits. Based on the results obtained during the first 
cycle, which have not shown maximum results and indicators of success that have not been achieved, the researcher decides to continue the next cycle.

\subsection{Description of Research Results in Cycle II}

In the first cycle consists of 4 meetings, namely 3 times the learning process with the material of Equation and Inequality Squares.

\subsubsection{Planning}

Planning carried out in the second cycle in general is the same as planning in the cycle II, but there are some improvements that are added after reflecting the results of the action in cycle II. The several improvements made are: (1) Replacement of groups is done without changing the group structure, namely groups in pairs. This change is based on the results of the first cycle test and is attempted in 1 group consisting of a student with high or moderate ability and the other is a student who is low or very low ability. (2) The teacher starts the lesson after the classroom atmosphere is truly conducive and students are ready to learn so that students focus more on the material to be learned. The teacher instructs that all activities outside mathematics be stopped first and prepare everything needed for the material to be studied. (3) The teacher motivates students to ask questions, respond, and dare to come forward both in the Sharing phase and when the teacher gives practice questions. The teacher informs that student courage is one aspect that is assessed by the teacher. (4) Teachers are more in control of student activities in learning and try as much as possible to minimize student activities that are negative such as playing, noisy, and so on. (5) The teacher multiplies the practice questions and homework to further deepen students' understanding of the material they have learned.

\subsubsection{Action}

Based on the reflection in the first cycle there were several improvements regarding the implementation of the action in the second cycle in order to maximize students' understanding of the material taught by: (1) Make group changes without changing the group structure, namely groups in pairs. (2) More motivating students to dare to ask questions, give responses, and dare to appear in front of the class. (3) More control of student activities in learning. (4) Increasing problem training and homework to further deepen students' understanding of the material they have learned. (5) Streamlining implementations that have been planned previously.

\subsubsection{Observating}

At this stage the observation is carried out to observe the activities of students during the learning process taking place using the cooperative learning type Think-Pair-Share (TPS). The results of observations of student activities can be seen in Table 6 .

Table 6. Results of observation of student activities during Cycle II

\begin{tabular}{|c|c|c|c|c|c|c|c|}
\hline \multirow{2}{*}{ No. } & \multirow{2}{*}{ Aspects studied } & \multicolumn{4}{|c|}{ Meeting } & \multirow{2}{*}{ Percentage } & \multirow{2}{*}{$\begin{array}{c}\text { Amount } \\
(\%)\end{array}$} \\
\hline & & I & II & III & IV & & \\
\hline 1. & $\begin{array}{l}\text { Students present during the learning } \\
\text { process take place. }\end{array}$ & 24 & 23 & 25 & \multirow{4}{*}{$\begin{array}{l}\mathrm{T} \\
\mathrm{E} \\
\mathrm{S} \\
\mathrm{T} \\
\mathrm{II}\end{array}$} & 72 & 96 \\
\hline 2. & $\begin{array}{l}\text { Students who ask questions to the } \\
\text { teacher. }\end{array}$ & 8 & 10 & 13 & & 31 & 41,32 \\
\hline 3 & $\begin{array}{l}\text { Students who answer the problem } \\
\text { questions taught by the teacher. }\end{array}$ & 6 & 9 & 11 & & 26 & 34,68 \\
\hline 4. & Active students come to the front of & 9 & 11 & 12 & & 32 & 41,32 \\
\hline
\end{tabular}




\begin{tabular}{|c|c|c|c|c|c|c|}
\hline \multicolumn{5}{|c|}{$\begin{array}{l}\text { the class doing independent } \\
\text { assignments. }\end{array}$} & & \\
\hline 5. & $\begin{array}{l}\text { Students who actively work together } \\
\text { during discussion in pairs. }\end{array}$ & 22 & 22 & 24 & 68 & 90,68 \\
\hline 6. & $\begin{array}{l}\text { Students who can present the results } \\
\text { of group discussions. }\end{array}$ & 10 & 12 & 16 & 38 & 50,68 \\
\hline 7. & $\begin{array}{l}\text { Students who do other activities } \\
\text { (noisy, playing, etc.). }\end{array}$ & 2 & 2 & 1 & 5 & 6,68 \\
\hline
\end{tabular}

Based on the student activity sheet in Table 6, it can be seen that: Students present during the learning process took place, at the first meeting as many as 24 people then decreased to the second meeting as many as 23 people and increased at the meeting III as many as 25 people. Students who asked questions to the teacher, at the first meeting as many as 8 people then increased in the second meeting as many as 10 people and again increased at the III meeting as many as 13 people. Students who answered the problem questions taught by the teacher, at the first meeting as many as 6 people then increased in the second meeting as many as 9 people and returned to the III meeting as many as 11 people. Active students come to the front of the class doing independent assignments, in the first meeting as many as 9 people then increased in the second meeting as many as 11 people and again increased at the III meeting as many as 12 people. Students who actively discuss with their partners (Pair), at the first meeting as many as 22 people then at the second meeting as many as 22 people and increased at the meeting III as many as 24 people. Students who present the results of their discussion in front of the class (Share), at the first meeting as many as 10 people then increased in the second meeting as many as 12 people and again increased at the III meeting as many as 16 people. Students who do other activities (playing, noisy, etc.), at the first meeting as many as 2 people and at the second meeting remain that is as many as 2 people then decreases at meeting III as many as 1 person.

\subsubsection{Evaluation}

Evaluation was carried out at the end of the second cycle to find out the extent of students' understanding of the material being taught. The instrument used was a test of learning outcomes in the form of daily tests after presentation of material for 3 meetings. The score for the acquisition of student learning outcomes after the application of the cooperative learning model type Think-Pair-Share (TPS) in the second cycle can be seen in Table 7.

Tabel 7. Statistics on the value of student learning outcomes in Cycle II

\begin{tabular}{lc}
\hline Statistics & Statistical Value \\
\hline Subject & 25 \\
Ideal score & 100 \\
Highest score & 98 \\
Lowest score & 61 \\
Score range & 37 \\
Average score & 84.88 \\
Mode & 90 \\
Median & 87 \\
Variance value & 76.28 \\
Standard deviation & 8.73 \\
\hline
\end{tabular}

After the score of learning outcomes is grouped into five categories, the frequency distribution and percentage are obtained as follows: 
International Journal on Teaching and Learning Mathematics

2019, Vol. 2, No. 2, pp. 67-77

P-ISSN: 2621-2188, E-ISSN: 2621-2196

Table 8. Frequency distribution and percentage of learning outcomes scores in Cycle II

\begin{tabular}{ccccc}
\hline No. & Score & Category & Frequency & Percentage \\
\hline 1. & $0-54$ & Very low & 0 & 0 \\
2. & $55-64$ & Low & 2 & 8 \\
3. & $65-79$ & Is being & 4 & 16 \\
4. & $80-89$ & High & 10 & 40 \\
5. & $90-100$ & Very high & 9 & 36 \\
\hline \multicolumn{7}{r}{} & Total & 25 & 100 \\
\hline
\end{tabular}

Based on Tables 7 and 8, it can be stated that students' mathematics learning outcomes after the action taken in the form of the cooperative learning model type Think-Pair-Share (TPS) in the second cycle average score of 84.88 from the ideal score of 100 in the category high. In addition, the highest score was 98 and the lowest score was 61 . Of the 25 students of class X3 of SMA Negeri 8 Pangkep, there were $0 \%$ of students whose learning levels were in the very low category, $8 \%$ were in the low category, $16 \%$ were in the moderate category, and in the high category $40 \%$ while in the very high category $36 \%$.

To see the percentage of completeness in learning mathematics students of class X3 Pangkep 8 High School after applying the cooperative model Think-Pair-Share (TPS) type in the second cycle can be seen in the following Table 9. Table 9 shows the percentage of mathematics learning outcomes of students who fall into the complete category of $92 \%$, namely 23 out of 25 students, while those included in the incomplete category are $8 \%, 2$ of 25 students.

Table 9. Description of completeness of student mathematics learning outcomes in Cycle II

\begin{tabular}{cccc}
\hline Score & Category & Frequency & Percentage \\
\hline $0-74$ & Not completed & 2 & 8 \\
$75-100$ & Completed & 23 & 92 \\
& Total & 25 & 100 \\
\hline
\end{tabular}

\subsubsection{Reflecting}

During the implementation of the second cycle of action obtained several advances where student activity is increasing, both during discussion in pairs and when working independently. Student interaction between teachers and students also increased. They are more courageous and enthusiastic about asking questions, expressing opinions, responding to their friends' answers and being motivated to present the results of their group activities even without being asked by the teacher. In addition, the number of students doing other activities is decreasing. They began to realize that the teacher's assessment was not only on the final exam, but also based on their activities during the learning process. They also realize that shared goals can be achieved through collaboration and active participation in groups. In general, students are used to it and increasingly like Think-Pair-Share (TPS) type of cooperative learning.

Based on the results above, in general it can be said that the activities in the second cycle experienced an increase compared to the first cycle. At the end of cycle II students were given tests to test their abilities, while still tightening supervision. As described in the quantitative analysis and qualitative analysis, the results obtained by students on the cycle II test experienced an increase from cycle I. Because the success indicators that have been determined in this study 
have been achieved, the researchers decided that this study was 2 cycles, and concluded that after implementation Think-Pair-Share (TPS) type of cooperative learning, there was an increase in mathematics learning outcomes in class X3 students of SMA 8 Pangkep.

In the final stage, the researcher asked all students of class X3 of SMA Negeri 8 Pangkep to respond / respond to the entire learning process after applying the cooperative model of the Think-Pair-Share (TPS) type from the initial meeting to the final meeting by filling out the questionnaire given.

Provision of student response questionnaires carried out at the end of the cycle II meeting. The results of the analysis of the response questionnaire of class X3 students at SMA Negeri 8 Pangkep towards learning by applying the cooperative learning model of the Think-Pair-Share (TPS) type given in cycle I and cycle II, can be seen in Table 10.

Table 10. Results of student response questionnaire analysis

\begin{tabular}{clcccc}
\hline No. & \multicolumn{1}{c}{ Question } & Yes & Percentage (\%) & No & Percentage (\%) \\
\hline 1. & Are you happy with math? & 25 & 100 & 0 & 0 \\
\hline 2. & $\begin{array}{l}\text { Do you like math by using a cooperative } \\
\text { model type Think Share (TPS)? }\end{array}$ & 25 & 100 & 0 & 0 \\
\hline 3. & $\begin{array}{l}\text { Are you motivated to learn mathematics, } \\
\text { after applying the Think Pair Share (TPS) } \\
\text { type cooperative model? }\end{array}$ & 23 & 92 & 2 & 8 \\
\hline 4. & $\begin{array}{l}\text { Does the cooperative pair type Think Pair } \\
\text { Share (TPS) model help and make it } \\
\text { easier for you to understand mathematics } \\
\text { subject matter? }\end{array}$ & 25 & 100 & 0 & 0 \\
\hline 5. & $\begin{array}{l}\text { Does the cooperative pair Think Pair } \\
\text { Share (TPS) type of learning make you an } \\
\text { active student? }\end{array}$ & 24 & 96 & 1 & 4 \\
\hline 6. & $\begin{array}{l}\text { Do you like to share your knowledge and } \\
\text { experience in applying the Cooperative } \\
\text { Think Pair Share (TPS) type model? }\end{array}$ & 25 & 100 & 0 & 0 \\
\hline & Total & & 3 & \\
\hline & Percentage & 98 & 2 & \\
\hline
\end{tabular}

Based on Table 10, it can be seen that students who are happy with mathematics as much as $100 \%$ and who do not like as much as $0 \%$, students who like to learn mathematics using cooperative learning models Think-Pair-Share (TPS) as much as $100 \%$ and those who do not like 0\%, students who are motivated to learn after applying the cooperative model Think Pair Share (TPS) type as much as $92 \%$ and unmotivated as much as $8 \%$, students who feel helped and easily understand mathematics subject matter using the cooperative learning model type Think Pair-Share (TPS) as much as $100 \%$ and not as much as $0 \%$, students who feel active by using the cooperative learning model Think-Pair-Share (TPS) as much as 96\% and not as much as $4 \%$, students who like to share knowledge and experience using $100 \%$ of the Think-PairShare (TPS) cooperative learning model.

\section{CONCLUSION}

This study found that the application of the cooperative learning with Think-Pair-Share type can improve mathematics learning outcomes. which can be seen from the average score of results student learning in cycle I reached 65 and students who completed as many as 6 people (24\%) and those who did not complete as many as 19 people (76\%), then the average score of student 
learning outcomes in cycle II reached 84.88 and students who completed as much 23 people $(92 \%)$ and those who did not complete 2 people $(8 \%)$.

\section{REFERENCES}

Almerino, P. M., Etcuban, J. O., De Jose, C. G., \& Almerino, J. G. F. (2019). Students' affective belief as the component in mathematical disposition. International Electronic Journal of Mathematics Education, 14(3), 475-487.

Chen, B., Chang, Y. H., Ouyang, F., \& Zhou, W. (2018). Fostering student engagement in online discussion through social learning analytics. The Internet and Higher Education, 37, 21-30.

Cotton, D. R., Warren, M. F., Maiboroda, O., \& Bailey, I. (2007). Sustainable development, higher education and pedagogy: A study of lecturers' beliefs and attitudes. Environmental Education Research, 13(5), 579-597.

Di Martino, P., \& Zan, R. (2010). 'Me and maths': Towards a definition of attitude grounded on students' narratives. Journal of Mathematics Teacher Education, 13(1), 27-48.

Fauzi, Z. A., \& Fikri, H. (2018). Improving learning activities using a combination of mind mapping model, think pair share and teams game tournament. In 1st International Conference on Creativity, Innovation and Technology in Education (IC-CITE 2018) (pp. 318-322). Atlantis Press.

Firdaus, A. M. (2019). Application of cooperative learning model type Think Pair Share (TPS) on mathematical communication ability. Daya Matematis: Jurnal Inovasi Pendidikan Matematika, 7(1), 59-68.

Githua, B. N., \& Mwangi, J. G. (2003). Students' mathematics self-concept and motivation to learn mathematics: Relationship and gender differences among Kenya's secondary-school students in Nairobi and Rift Valley provinces. International Journal of Educational Development, 23(5), 487-499.

Gravemeijer, K., Stephan, M., Julie, C., Lin, F. L., \& Ohtani, M. (2017). What mathematics education may prepare students for the society of the future?. International Journal of Science and Mathematics Education, 15(1), 105-123.

Huang, M. Y., Tu, H. Y., Wang, W. Y., Chen, J. F., Yu, Y. T., \& Chou, C. C. (2017). Effects of cooperative learning and concept mapping intervention on critical thinking and basketball skills in elementary school. Thinking Skills and Creativity, 23, 207-216.

Johnson, D. W., Johnson, R. T., \& Smith, K. (2007). The state of cooperative learning in postsecondary and professional settings. Educational Psychology Review, 19(1), 15-29.

Kemmis, S., McTaggart, R., \& Nixon, R. (2013). The action research planner: Doing critical participatory action research. Springer Science \& Business Media.

Kiemer, K., Gröschner, A., Pehmer, A. K., \& Seidel, T. (2015). Effects of a classroom discourse intervention on teachers' practice and students' motivation to learn mathematics and science. Learning and Instruction, 35, 94-103.

Kuznetsova, E., \& Matytcina, M. (2018). A multidimensional approach to training mathematics students at a university: improving the efficiency through the unity of social, psychological and pedagogical aspects. International Journal of Mathematical Education in Science and Technology, 49(3), 401-416.

Mundriyah, M., \& Parmawati, A. (2016). Using Think-Pair-Share (TPS) to improve students'writing creativity (A classroom action research in the second semester students of STKIP Siliwangi Bandung). Jurnal Ilmiah P2M STKIP Siliwangi, 3(2), 84-91. 
Munir, M. T., Baroutian, S., Young, B. R., \& Carter, S. (2018). Flipped classroom with cooperative learning as a cornerstone. Education for Chemical Engineers, 23, 25-33.

Ng, C. H. C. (2018). High school students' motivation to learn mathematics: The role of multiple goals. International Journal of Science and Mathematics Education, 16(2), 357375.

Siregar, M. F., Amry, Z., \& Syafari. (2017). The application of cooperative learning of ThinkPair-Share (TPS) type to increase the students' ability of problem-solving. In Proceedings of The 2nd Annual International Seminar on Transformative Education and Educational Leadership (pp. 320-323). State University of Medan.

van Es, E. A., Cashen, M., Barnhart, T., \& Auger, A. (2017). Learning to notice mathematics instruction: Using video to develop preservice teachers' vision of ambitious pedagogy. Cognition and Instruction, 35(3), 165-187.

Zan, R., \& Di Martino, P. (2007). Attitude toward mathematics: Overcoming the positive/negative dichotomy. The Montana Mathematics Enthusiast, 3(1), 157-168. 